\title{
FEATHER DEGRADATION BY STRAINS OF BACILLUS ISOLATED FROM DECOMPOSING FEATHERS
}

\author{
Swetlana Nagal*, P. C. Jain \\ Department of Applied Microbiology and Biotechnology, Dr. H. S. Gour Vishwavidyalaya, Sagar, India.
}

Submitted: March 14, 2009; Returned to authors for corrections: May 05, 2009; Approved: July 24, 2009.

\begin{abstract}
Feather waste is generated in large amounts as a by-product of commercial poultry processing. This residue is almost pure keratin, which is not easily degradable by common proteolytic enzymes. Eight strains of Bacillus, isolated from decomposing feathers were tested for the hydrolysis of feather wastes in the laboratory. Among these strains, Bacillus cereus KB043 was the best feather degrading organism when grown on basal medium containing $1 \%$ hen feather as sole source of carbon and nitrogen. It caused $78.16 \pm$ $0.4 \%$ degradation with a significant release of soluble protein $\left(1206.15 \pm 14.7 \mu \mathrm{g} \mathrm{mL}^{-1}\right)$ and cysteine $\left(20.63 \pm 0.4 \mu \mathrm{g} \mathrm{mL}^{-1}\right)$ in the cultivation fluid. The strain also showed the highest level of keratinase activity $\left(39.10 \pm 0.4 \mathrm{U} \mathrm{mL}^{-1}\right)$. These data indicates that the Bacillus cereus $\mathrm{KB} 043$ could be useful in management of poultry wastes.
\end{abstract}

Key words: Bacillus; Feather degradation; Poultry waste; Soluble protein; Keratinase.

Feather is composed of over $90 \%$ protein, the main component being keratin, a fibrous and insoluble protein highly cross-linked with disulphide and other bonds. In mature chicken feather accounts up to $5-7 \%$ of the live weight. Worldwide, several million tons of feathers are generated annually as waste by poultry-processing industries. Considering its high protein content, this waste could have a great potential as a source of protein and amino acids for animal feed and for many other applications.

Despite the recalcitrance, keratin wastes can be efficiently degraded by specific proteases such as keratinase (15). The production of keratinases has been a domain of saprophytic and dermatophytic fungi, actinomycetes and some Bacillus species (2, 7, 11, 21, 23). Hydrolysis of feathers by microorganisms possessing keratinolytic activity represents an attractive alternatives method for improving the nutritional value of feather meal, compared to currently used physiochemical methods (1, 16, 24). Keratinases could also play other important role in biotechnological applications like removal of hairs and feathers in leather and poultry industries, aerobic digestion of poultry waste to generate natural gas, in textile industries to improve shrink proofing wool and for cleaning obstructions in sewage system during wastewater treatment (3).

The present report deals with feather degradation and production of keratinase by selected strains of Bacillus isolated from decomposing feathers. Preliminary screening of 126 isolates of bacteria for degradation of feather in vitro showed that only $35 \%$ of the examined strains were able to grow on feather as sole source of carbon and nitrogen (13). On the basis of extent of feather degradation eight promising isolates were

*Corresponding Author. Mailing address: Department of Applied Microbiology and Biotechnology, Dr. H. S. Gour Vishwavidyalaya, Sagar. (INDIA).; Email: swetlana_micro@yahoo.com 
selected for further studies. Bacterial identification was conducted based on morphological, physiological and biochemical tests and the results were compared with Bergey's Manual of Determinative Bacteriology, $8^{\text {th }}$ edition (5) and The Genus Bacillus: Agriculture Handbook No. 427 (9). These strains were identified as Bacillus cereus (KB043), B. licheniformis (KB059), B. megaterium (KB008 and KB069), B. subtilis (KB099), and Bacillus sp. (KB037, KB081and KB087) and the results were summarized in Table 1. Previous literatures have also documented the isolation of keratinase producing strains from members of genus Bacillus $(8,17,20)$.

Table 1. Morphological, physiological and biochemical comparison of Bacillus strains isolated from decomposing feathers.

\begin{tabular}{|c|c|c|c|c|c|c|c|c|c|}
\hline Tests & & \multicolumn{8}{|c|}{ Bacillus strains } \\
\hline Gram staining & & + & + & + & + & + & + & + & + \\
\hline Motility & & + & + & - & + & + & - & - & + \\
\hline \multirow[t]{3}{*}{ Growth in $\mathrm{pH}$} & 5.0 & - & $\mathrm{W}$ & + & + & - & $\mathrm{W}$ & - & - \\
\hline & 6.0 & + & + & + & + & - & + & + & - \\
\hline & 9.0 & + & + & + & + & + & + & + & + \\
\hline \multirow{4}{*}{$\begin{array}{l}\text { Growth at } \\
\text { temperature }\end{array}$} & $10^{\circ} \mathrm{C}$ & - & - & - & + & - & - & - & - \\
\hline & $25^{\circ} \mathrm{C}$ & + & + & W & + & + & + & + & + \\
\hline & $35^{\circ} \mathrm{C}$ & + & + & + & + & + & + & + & + \\
\hline & $45^{\circ} \mathrm{C}$ & + & + & + & + & - & + & + & + \\
\hline Growth in $\mathrm{NaCl}$ & $10 \%$ & - & - & - & - & - & + & - & - \\
\hline \multirow{11}{*}{$\begin{array}{l}\text { Anaerobic growth } \\
\text { Growth in } \\
\text { carbohydrates }\end{array}$} & & - & - & + & + & - & + & + & - \\
\hline & Glucose & + & - & + & + & - & + & - & + \\
\hline & Arabinose & - & - & + & + & - & - & - & + \\
\hline & Galactose & + & - & + & - & + & + & - & - \\
\hline & Cellibiose & - & - & - & + & + & - & + & - \\
\hline & Melizitose & - & - & - & - & - & - & + & - \\
\hline & Ribose & + & - & - & + & - & - & + & - \\
\hline & Maltose & + & - & - & + & - & - & + & + \\
\hline & Fructose & - & - & - & + & + & - & + & - \\
\hline & Sucrose & - & - & + & + & - & + & + & - \\
\hline & Xylose & - & - & - & + & - & - & - & + \\
\hline \multirow[t]{5}{*}{ Biochemical tests } & Catalase & + & + & + & + & + & + & + & + \\
\hline & Oxidase & + & - & + & + & + & - & + & + \\
\hline & VP test & - & - & - & + & - & - & - & - \\
\hline & $\mathrm{NO}_{3}$ reduction & + & - & + & + & + & + & - & + \\
\hline & Urease & - & + & - & - & - & - & - & - \\
\hline
\end{tabular}

+ , Positive; -, Negative; W, Weak Growth. 
Feather degradation by the selected Bacillus strains was carried out in $150 \mathrm{ml}$ Erlenmeyer flasks containing $50 \mathrm{ml}$ of basal medium $\left(\mathrm{K}_{2} \mathrm{HPO}_{4} 0.4 \mathrm{~g} \mathrm{~L}^{-1} ; \mathrm{MgSO}_{4} .7 \mathrm{H}_{2} \mathrm{O} 0.05 \mathrm{~g} \mathrm{~L}^{-1}\right.$; $\mathrm{NaCl} 0.05 \mathrm{~g} \mathrm{~L}^{-1} ; \mathrm{FeCl}_{3} 0.01 \mathrm{~g} \mathrm{~L}^{-1}, \mathrm{pH} 7.0$ ) with $0.5 \mathrm{~g}$ hen feathers. Bacterial culture grown on nutrient broth at $37^{\circ} \mathrm{C}, 150$ rev $\min ^{-1}$ for $24 \mathrm{~h}$ was used as inoculum $(2 \% \mathrm{v} / \mathrm{v})$. The flasks were incubated at $37^{\circ} \mathrm{C}$ at $150 \mathrm{rev} \mathrm{min}^{-1}$ for six days.

Residual feather in the culture broth was harvested by filtration with Whatman number 1 filter paper, washed with distilled water and dried at $65^{\circ} \mathrm{C}$ to constant weight. The percentage of feather degradation was calculated from the difference in residual feather dry weight between control (Feather without bacterial inoculation) and treated sample (13). The culture filtrates was analyzed for soluble protein content by Folin Phenol method (12). The free cysteine content in the culture filtrate was determined by the method as described by Saville (19).

Keratinase activity was determined using keratin azure as substrate (Sigma, USA) (4). One mL of enzyme sample was incubated with $40 \mathrm{mg}$ of keratin azure in $8 \mathrm{~mL}$ of Tris- $\mathrm{HCl}$ buffer $(0.1 \mathrm{M}, \mathrm{pH} 9.0)$ at $50^{\circ} \mathrm{C}$ for $1 \mathrm{~h}$. The reaction was stopped using 5\% TCA and samples were centrifuged at 10,000 $\mathrm{g}$ for $10 \mathrm{~min}$ and the absorbance of the supernatant was determined at $540 \mathrm{~nm}$. In enzyme blanks TCA solution were added before reaction. One unit of keratinase was defined as the amount of the enzyme that resulted in an increase in absorbance at $595 \mathrm{~nm}$ of 0.01 after the reaction with keratin azure at $\mathrm{pH} 9.0$ and $50^{\circ} \mathrm{C}$ for $1 \mathrm{~h}$.

Among all the strains, Bacillus cereus KB043 showed maximum degradation i.e., $78.16 \pm 0.4 \%$ weight loss (Table 2). In the present study local isolates of B. licheniformis KB059 and B. subtilis KB099 showed $74.39 \pm 2.1$ and $73.41 \pm 0.7 \%$ feather degradation, respectively. El-Refai et al. (6) reported $87.2 \%$ degradation in Bacillus licheniformis and $49.4 \%$ weight loss in cultures of Bacillus subtilis when grown on basal medium supplemented with $1 \%$ hen feathers.

Table 2. Keratinolytic activity of Bacillus strains isolated from decomposing feathers.

\begin{tabular}{|c|c|c|c|c|c|c|}
\hline S.N & Organism & $\begin{array}{c}\text { Weight Loss } \\
\text { (\%) }\end{array}$ & Final pH & $\begin{array}{c}\text { Free } \\
\text { Cysteine } \\
\left(\mu \mathrm{g} \mathrm{mL}^{-1}\right)\end{array}$ & $\begin{array}{l}\text { Soluble protein } \\
\qquad\left(\mu \mathrm{g} \mathrm{mL}^{-1}\right)\end{array}$ & $\begin{array}{l}\text { Keratinase } \\
\left(\mathrm{U} \mathrm{mL}^{-1}\right)\end{array}$ \\
\hline 1. & Bacillus megaterium KB008 & $68.83 \pm 1.3$ & $8.42 \pm 0.02$ & $15.56 \pm 0.2$ & $1217.69 \pm 10.8$ & $26.15 \pm 0.3$ \\
\hline 2. & Bacillus sp KB037 & $62.04 \pm 1.6$ & $8.12 \pm 0.04$ & $14.78 \pm 0.6$ & $641.15 \pm 24.3$ & $16.95 \pm 0.4$ \\
\hline 3. & Bacillus cereus $\mathrm{KB} 043$ & $78.16 \pm 0.4$ & $9.38 \pm 0.02$ & $20.63 \pm 0.4$ & $1206.15 \pm 14.7$ & $39.10 \pm 0.4$ \\
\hline 4. & Bacillus licheniformis KB059 & $74.39 \pm 2.1$ & $9.24 \pm 0.11$ & $18.85 \pm 0.2$ & $1294.84 \pm 18.7$ & $31.50 \pm 1.2$ \\
\hline 5. & Bacillus megaterium KB069 & $68.86 \pm 1.3$ & $9.01 \pm 0.12$ & $15.22 \pm 0.0$ & $1133.84 \pm 16.3$ & $18.80 \pm 0.3$ \\
\hline 6. & Bacillus sp KB081 & $71.50 \pm 0.3$ & $9.22 \pm 0.01$ & $18.95 \pm 1.1$ & $1088.46 \pm 22.1$ & $29.35 \pm 0.1$ \\
\hline 7. & Bacillus sp KB087 & $61.8 \pm 0.5$ & $7.90 \pm 0.06$ & $13.92 \pm 0.1$ & $448.8 \pm 15.9$ & $18.05 \pm 0.1$ \\
\hline 8. & Bacillus subtilis KB099 & $73.41 \pm 0.7$ & $9.11 \pm 0.05$ & $16.24 \pm 1.2$ & $995.38 \pm 11.9$ & $25.40 \pm 0.1$ \\
\hline
\end{tabular}

Test strains were grown on basal medium supplemented with $1 \%$ feathers (Initial pH 7.0) and incubated at $37^{\circ} \mathrm{C}, 150 \mathrm{rpm}$ for six days.

Readings are presented as Mean \pm SD. 
An increase in $\mathrm{pH}$ values was observed during feather degradation which is indicative of keratinolytic potential of microorganisms. Organism with higher keratinolytic activity turns media more alkaline in comparison with those exhibiting lower keratinolytic activities (18). This observation was based on the facts that keratin degradation involves oxidative deamination which results in production of ammonia and thereby increases the $\mathrm{pH}$ value.

Sulphitolysis is the primary process in keratin degradation; it involves breakage of disulphide linkages and release of cysteine residues as thiol. Bacillus cereus KB043 showed the accumulation of highest amount of cysteine i.e. $20.63 \pm 0.4$ $\mu \mathrm{gmL}^{-1}$ while, Bacillus sp. (KB087) showed minimum release of cysteine residue $\left(13.92 \pm 0.1 \mu \mathrm{gmL}^{-1}\right)$ in its cultivation fluid. Accumulation of cysteine also suggests the presence of disulfide reductase activity (17).

The amount of soluble protein released into the culture filtrate varied among the different Bacillus strains. Bacillus licheniformis KB059 showed the highest accumulation of soluble protein i.e. $1294.84 \pm 18.7 \mu \mathrm{gmL}^{-1}$. The final concentration of protein in cultivation fluid was similar for $B$. megaterium KB008 and B. cereus KB043. Kim et al. (10) have reported $0.7 \mathrm{mgmL}^{-1}$ soluble protein in culture of Bacillus growing on $1 \%$ feather medium.

The cultivation fluid of Bacillus cereus KB043 showed the highest keratinase activity $\left(39.1 \pm 0.4 \mathrm{UmL}^{-1}\right)$, which is followed by $B$. licheniformis KB059 (31.5 $\left.\pm 1.2 \mathrm{UmL}^{-1}\right)$. Keratinase values were quiet low in case of Bacillus sp. KB037 and $\mathrm{KB} 087$ ranging from $16.95 \pm 0.4$ to $18.05 \pm 0.1 \mathrm{UmL}^{-1}$. The production of extracellular keratinase during growth of keratinophilic microorganism is well established $(14,22,25)$. Suntornsuk and Suntornsuk (20) reported growth and efficient utilization of feather by Bacillus sp. FK 46 with release of 0.9 $\mathrm{UmL}^{-1}$ of keratinase.

In the light of our results, Bacillus cereus $\mathrm{KB} 043$ is a potential keratinolytic strain which is suitable for the bacterial degradation of keratin wastes and its fermentation broth could be useful in processes suitable for the conversion of feather to feed stock additives.

\section{REFERENCES}

1. Bertsch, A.; Coello, N; (2005). A biotechnological process for treatment and recycling poultry feathers as a feed ingredient. Biores. Technol., 96, 1703-1708.

2. Bockle, B.; Muller, R. (1997). Reduction of disulphide bonds by Streptomyces pactum during growth on chicken feathers. Appl Environ Microbiol., 63, 7990-7992.

3. Brandelli, A. (2008). Bacterial Keratinases: Useful Enzymes for bioprocessing agroindustrial wastes and beyond. Food Bioprocess Technol., 1, 105-116.

4. Bressollier, P.; Letourneau, F.; Urdaci, M.; Verneuil, B. (1999). Purification and characterization of a keratinolytic serine proteinase from Streptomyces albidoflavus. Appl. Environ. Microbiol., 65, 2570-2576.

5. Buchanan, R.E.; Gibbons, N.E. (1974). Bergey's Manual of Determinative Bacteriology, Eighth Edition. The Williams and Wilkins Co., Baltimore.

6. El-Refai, H.A.; AbdelNaby, M.A.; Gaballa, A.; El-Araby, M.H.; Fatah, A.F.A. (2005). Improvement of the newly isolated Bacillus pumilus FH9 Keratinolytic activity. Process Biochem., 40, 2325-2332.

7. Friedrich, J.; Gradisar, H.; Mandin. D; Chaumount, J.P. (1994). Screening fungi for synthesis of keratinolytic enzymes. Lett Appl Microbiol., 28, 127-130.

8. Geessess, A.; Kaul, R.H.; Gashe, B.A.; Mattiasson, B. (2003). Novel alkaline proteases from alkaliphilic bacteria grown on chicken feather. Enzyme and Microbial Technol., 32, 519-524.

9. Gordon, Ruth E.; William, C.; Haynes, Hor-Nay Pang, C. (1973. The Genus Bacillus: Agriculture Handbook No. 427. ARS-USDA, Washington, D.C

10. Kim, J.M.; Lim, W.J.; Suh, H.J. (2001). Feather-degrading Bacillus species from poultry waste. Process Biochem., 37, 287-291.

11. Lin, X.; Lee, C.G.; Casale, E.S.; Shih, J.C.H. (1992). Purification and characterization of a keratinase from a feather - degrading Bacillus licheniformis strain. Appl Environ Microbiol., 58, 3271- 3275.

12. Lowry, O.H.; Rosenbrough, N.J.; Farr, A.L.; Randall, R.J. (1951). Protein measurement with the folin Phenol Reagent. Jour Bio Chem., 193, 265-275.

13. Nagal, S.; Jain, P.C. (2009). Isolation of keratinolytic bacteria from decomposing feathers. Journal of Microbial world, 11 (1) 15-20.

14. Noval, J.J.; Nickeron, W.J. (1959). Decomposition of native keratin by Streptomyces fradiae. J. Bacteriol., 77, 251-259.

15. Onifade, A.A.; Al-Sane, N.A.; Al-Musallam, A.A.; Al-Zarban, S. (1998). Potentials for biotechnological applications of keratin-degrading microorganisms and their enzymes for nutritional improvement of feathers and other keratins as livestock feed resources. Biores. Technol., $66,1-11$.

16. Papadopoulos, M.C.; El Boushy, A.R.; Roodbeen, A.E.; Ketelaars, E.H. (1986). Effects of processing time and moisture content on amino acid 
Nagal, S. et al.

composition and nitrogen characteristics of feather meal. Animal Feed Sci. Technol., 14, 279-290.

17. Rodziewicz, A.; Laba, W. (2008). Biodegradation of feather keratin by Bacillus cereus in pure culture and compost. EJPAU 11(2) \#03[ISSN1505-0297]

18. Sangali, S.; Brandelli, A. (2000). Feather keratin hydrolysis by a Vibrio sp. kr2 strain. J. Appl. Microbiol., 89,735-743.

19. Saville, B. (1958). A scheme for colorimetric determination of microgram amount of thiols. Analyst, 83, 670-72.

20. Suntornsuk, W.; Suntornsuk, L. (2003). Feather degradation by Bacillus sp. FK 46 in submerged cultivation. Bioresour Technol., 86, 239-243.

21. Takami, H.; Nogi, Y.; Horikoshi, K. (1999). Reidentification of the keratinase-producing facultatively alkaliphilic Bacillus sp no AH-101 as
Bacillus halodurans. Extremophiles, 3, 293-296.

22. Takiuchi, I.; Higuchi, D.; Sei, Y.; Koga, M. (1982). Isolation of an extracellular proteinase (keratinase) from Microsporum canis. Sabouraudia, 20, 281-288.

23. Wawrzkiewicz, K.; Wolski, T.; Lobarzawski, J. (1991). Screening the keratinolytic activity of dermatophytes in vitro. Mycopathologia, 114, 18.

24. Williams, C.M.; Lee, C.G.; Garlich, J.D.; Shih, J.C.H. (1991). Evaluation of a bacterial feather fermentation product, feather lysate, as a feed protein. Poultry Science, 70, 85-94.

25. Yu, R.J.; Harmon, S.R.; Grappel, S.F.; Blank, F. (1971). Two cell-bound keratinases of Trichophyton mentagrophytes. J. Invest. Dermatol., 55, 27 32. 